\title{
The Effect of Online Learning on Students' Learning Achievement on Colloid Concept
}

\author{
Ni Kadek Sri Sasmita ${ }^{1 *}$, I Wayan Redhana ${ }^{2}$, I Wayan Suja ${ }^{2}$ \\ ${ }^{I}$ Natural Science Study Program, Universitas Pendidikan Ganesha, Indonesia \\ ${ }^{2}$ Chemistry Education Study Program, Universitas Pendidikan Ganesha, Indonesia \\ *Corresponding author.Email: kadeksasmita96@gmail.com
}

\begin{abstract}
The era of the Covid-19 pandemic has encouraged learning to take place online. The development of technology and information was increasingly advanced to support online learning. This study aimed at describing the effect of online learning on high school students' learning achievement. This type of research was a quasi-experiment with a nonequivalent control group design. The population in this study was all students of the eleventh-grade students majoring in Mathematics and Natural Science at Public High School 1 South Kuta, Badung, Bali, Indonesia. The samples were selected using a cluster random sampling technique. An experimental group 1 was taught by online learning of Google Classroom, while an experimental group 2 was taught by online learning of WhatsApp group. The data were collected by giving tests before and after learning. Data were analyzed by descriptive and inferential statistics. The results showed that students' learning achievement taught by online learning of the Google Classroom was better than that of the WhatsApp group. The online learning has a positive impact on students' learning achievement.
\end{abstract}

Keywords: Google Classroom, learning achievement, online learning, WhatsApp group

\section{INTRODUCTION}

The Covid-19 pandemic is currently sweeping the entire world. The Covid-19 pandemic has greatly affected the education sector. The government issued circular number 4 of 2020 years as an effort to prevent the spread of Covid19. The circular contains the implementation of learning carried out from home [1]. Based on these conditions, the teacher must continue to ensure that learning activities can be carried out properly. This pandemic condition requires learning to be done online. The teacher as a facilitator must be able to create innovative learning so that students learn fun [2].

The online learning can be supported by learning applications that have developed at this time so that the learning process can be carried out properly. The online learning applications are currently very important to be utilized in the learning process because technology is increasingly sophisticated [3]. The online learning is effective because learning can be done anywhere and anytime by utilizing modern technology that has developed [4]. The online learning is growing rapidly along with the advancement of technology and information [5]. The use of technology in online learning is expected to improve the skills of teachers and students so that learning is more effective and learning objectives are well achieved [6].

The development of technology and information that is getting faster has an impact on the learning process [7]. Increasingly sophisticated technology can be used in the online learning process. Many online learning applications can support the learning process. Several learning applications that can support online learning are Google Classroom, WhatsApp group, zoom cloud meetings, Cisco WebEx meetings, Google meet, Schoology, and many other applications [8]. The learning application certainly has its advantages and disadvantages [9].

This study used Google Classroom as an online learning application to support the learning process. Google Classroom is a free application developed by Google that aims to support the learning process [7]. Google Classroom has several advantages, including facilitating interaction between teachers and students or students and students, reducing paper usage (paperless), learning features, and more flexible learning [7],[9]. Online learning using Google Classroom can change learning to 
be student-centered, increase students' learning motivation, think creatively, and improve problem-solving skills [5]. Based on this, this study aimed at describing the effect of online learning on students' learning achievement.

\section{METHODOLOGY}

This type of study is a quasi-experimental research, because not all the variables that arise and the experimental conditions can be strictly regulated and controlled. The research design used was the nonequivalent control group design. The research design of the nonequivalent control group design is a research design that provides a pretest without randomly selecting either the experimental group 1 or the experimental group 2 so that the treatment results can be known more accurately. Before starting the learning process, both groups were given a pretest which aimed to determine the extent to which the two groups had prior knowledge. After being given treatment in the form of learning, the two groups were given a posttest which aimed to determine the learning achievement of the two groups after learning.

The population of this study was all students of grade XI in Mathematics and Natural Science at Public High School 1 South Kuta, Badung, Bali, Indonesia. The samples were selected using cluster random sampling technique. The experimental group 1 is a class that was taught by online learning of Google Classroom, while the experimental group 2 is a class that was taught by online learning of WhatsApp group.

The instrument used in this study was a test of students' learning achievement. The tests used in this study were pretest and posttest. It used was the test that can measure students' learning achievement in the cognitive domain. The learning achievement test used in the pretest and posttest sessions are the same. The type of test used was an objective test (multiple choice) which is given online using the Google form.

The data obtained in this study were students' learning achievement scores. These data were analyzed using descriptive statistics and analysis of covariance (ANCOVA). All analysis of descriptive and inferential statistics were carried out with the help of SPSS software at the $5 \%$ significance level.

\section{RESULTS AND DISCUSSION}

In this study, the experimental group 1 was taught by online learning of Google Classroom and the experimental group 2 was taught by online learning of WhatsApp group. The learning achievement data obtained were in the form of pretest and posttest scores of the experimental group 1 and the experimental group 2, respectively. A descriptive statistical analysis produced a summary of students' learning achievement based on pretest and posttest scores (Table 1).

Table 1. Summary of student's pretest and posttest scores

\begin{tabular}{llll}
\hline Data & Statistics & $\begin{array}{l}\text { Experimental } \\
\text { group 1 }\end{array}$ & $\begin{array}{l}\text { Experimental } \\
\text { group 2 }\end{array}$ \\
\hline Pretest & Lowest score & 4.0 & 8.0 \\
& Highest score & 48.0 & 44.0 \\
& Mean score & 26.1 & 23.8 \\
& Standard & 12.7 & 11.0 \\
& deviation & 56.0 & 52.0 \\
Posttest & Lowest score & 54.0 & 84.0 \\
& Highest score & 92.0 & 68.7 \\
& $\begin{array}{l}\text { Mean score } \\
\text { Standard }\end{array}$ & 74.8 & 9.5 \\
\hline & 10.0 & \\
\hline
\end{tabular}

Based on Table 1, the posttest mean score of experimental group 1 is 74.8 , while the experimental group 2 is 68.7. The results showed that the mean score posttest of the group was taught by online learning of Google Classroom was higher than that was taught by online learning of WhatsApp group.

The data analysis technique used for hypothesis testing is the analysis of covariance (ANCOVA). Before testing the hypothesis, assumption tests were carried out which consisted of a normality test, a homogeneity test of variance between groups, a linearity test, and an interaction test. The results of data analysis on students' learning achievement using the ANCOVA technique were presented in Table 2.

The result of the analysis showed that the significance value was $0.042(<0.05)$ so that $\mathrm{H} 0$ was rejected or $\mathrm{H} 1$ was accepted. This indicated that students' learning achievement taught by online learning of the Google Classroom was better than that of the WhatsApp group. The online learning has a positive impact on students' learning achievement [4], [10][12]. The online learning is effective because the learning can be done anywhere and anytime by utilizing modern technology that has developed [4]. The use of technology in online learning is expected to improve the skills of teachers and students so that learning is more effective and learning objectives are well achieved [6]. The online learning can increase motivation and student's learning achievement because the online learning can create a learning process that is fun, student-centered, and flexible [2], [13]. The online learning can improve students' critical thinking skills, creative thinking skills, and improve problem solving skills [5], [14]. 
Table 2. Hypothesis test results

\begin{tabular}{llllll}
\hline Source & $\begin{array}{l}\text { Type III Sum } \\
\text { of Squares }\end{array}$ & df & Mean Square & F & Sig. \\
\hline $\begin{array}{l}\text { Corrected } \\
\text { Model }\end{array}$ & $3352.751 \mathrm{a}$ & 2 & 1676.376 & 33.005 & 0.000 \\
Intercept & 45897.316 & 1 & 45897.316 & 903.647 & 0.000 \\
Pretest & 2758.105 & 1 & 2758.105 & 54.303 & 0.000 \\
Learning & 218.730 & 1 & 218.730 & 4.306 & 0.042 \\
Error & 3047.471 & 60 & 50.791 & & \\
Total & 331985.000 & 63 & & & \\
Corrected & 6400.222 & 62 & & & \\
Total & & & & \\
\hline
\end{tabular}

In this study, the online learning of Google Classroom better than the online learning of WhatsApp group because Google Classroom has features that are structured to support the learning process. A virtual classroom is an online classroom that allows participants to communicate with one another, view presentations or videos, interact with other participants, and engage with resources in work groups [15].

The Google Classroom application can be used on computers, laptops, or cellphones. Google Classroom is designed for facilitating the interaction of teachers and students in cyberspace. This application delivers opportunities for teachers to explore students' scientific ideas. The online learning using the Google Classroom provides new experiences for students in the learning process so that it makes students enthusiastic and motivated to learn [5], [7], [16].

Google Classroom is considered as one of the online learning platforms that can support learning because this platform can be easily understood by students and teachers [15]. Google Classroom has structured features allowing users to create virtual classrooms so that the Google Classroom is effectively to support the learning process [5]. Learning using Google Classroom can create learning convenience for students and teachers [7]. The use of Google Classroom in online learning is an effort to simplify and streamline time so that its application can have a positive impact on students' learning achievement [9]. Some of the advantages of using Google Classrooms are as follow, including being able to create virtual classrooms, easier access, easier assignment delivery, reducing paper usage (paperless), easier access to materials and assignments given by the teacher, being able to be in a virtual classroom anytime and anywhere, receiving feedback assignments that have been created, sharing resources related to learning, being easy to obtain, use storage time, direct storage via Google drive, and viewing other materials or documents at any time [5], [7], [17], [18].

\section{CONCLUSION}

The online learning has a positive impact on students' learning achievement. The students' learning achievement taught by online learning of the Google Classroom was better than that of the WhatsApp group. The online learning using the Google Classroom provides new experiences for students in the learning process so that it makes students enthusiastic and motivated to learn. The Google Classroom used in online learning is an effort to simplify and streamline time so that its use can have a positive impact on students' learning achievement

\section{REFERENCES}

[1] J. Nummijoki, Y. Engeström, A. Sannino. Defensive and expansive cycles of learning: A study of home care encounters. Journal of the Learning Sciences, 27 (2) (2018) 224-264. DOI: https://doi.org/10.1080/1050840 6.2017 .1412970

[2] D. Dhawan. Online learning: A panacea in the time of COVID-19 crisis. Journal of Educational Technology Systems, 49 (1) (2020) 5-22. DOI: https://doi.org/10.11 $77 / 0047239520934018$

[3] D. Xu, S. S. Jaggars. The impact of online learning on students' course outcomes: Evidence from a large community and technical college system. Economics of Education Review, 37 (2013) 46-57. DOI: https://doi.or g/10.1016/j.econedurev.2013.08.001

[4] K. C. Chen, S. J. Jang. Motivation in online learning: Testing a model of self-determination theory. Computers in Human Behavior, 26 (4) (2010) 741-752. DOI: https://doi.org/10.1016/j.chb.2010.01.01 
[5] C. W. Cook, C. Sonnenberg. Technology and online education: Models for change. Contemporary Issues in Education Research (CIER), 7 (3) (2014) 171-188. DOI: https://doi.org/10.19030/cier.v7i3.8638

[6] A. Y. Ni. Comparing the effectiveness of classroom and online learning: Teaching research methods. Journal of Public Affairs Education, 19 (2) (2013) 199215. DOI: https://doi.org/10.1080/15236803.2013.1200 1730

[7] D. Marinova, K. de Ruyter, M. H. Huang, M. L. Meuter, G. Challagalla. Getting smart: Learning from technology-empowered frontline interactions. Journal of Service Research, 20 (1) (2017) 29-42. DOI: https:// doi.org/10.1177/1094670516679273

[8] S. Çankaya, G. Durak. Integrated Systems In Emergency Distance Education: The Microsoft Teams. Necatibey Faculty Of Education Electronic Journal Of Science \& Mathematics Education, 14 (2) (2020) 56-60. DOI: https://doi.org/10.17522/balikesirn ef.827595

[9] G. Battineni, G. G. Sagaro, N. Chinatalapudi, F. Amenta. Applications of machine learning predictive models in the chronic disease diagnosis. Journal of personalized medicine, 10 (2) (2020) 21. DOI: https:// doi.org/10.3390/jpm10020021

[10] R. M. Bernard, A. Brauer, P. C. Abrami, M. Surkes. The development of a questionnaire for predicting online learning achievement. Distance education, 25 (1) (2004) 31-47. DOI: https://doi.org/10. $1080 / 0158791042000212440$

[11] N. S. Lindsey, M. L. Rice. Interpersonal Skills and Education in the Traditional and Online Classroom Environments. Journal of Interactive Online Learning, 13 (3) (2015) 66.

[12] Y. Chen, Q. Zheng, S. Ji, F. Tian, H. Zhu, M. Liu. Identifying at-risk students based on the phased prediction model. Knowledge and Information Systems, 62 (3) (2020) 987-1003.

[13] C. H. H. Tsay, A. Kofinas, J. Luo. Enhancing student learning experience with technology-mediated gamification: An empirical study. Computers \& Education, 121 (2018) 1-17. DOI: https://doi.org/10. 1016/j.compedu.2018.01.009

[14] E. E. Peter. Critical thinking: Essence for teaching mathematics and mathematics problem solving skills. African Journal of Mathematics and Computer Science Research, 5 (3) (2012) 39-43. DOI: https://doi.org/ 10.5897/AJMCSR11.161
[15] F. Martin, M. A. Parker, D. F. Deale. Examining interactivity in synchronous virtual classrooms. International Review of Research in Open and Distributed Learning, 13 (3) (2012) 227-261. DOI: https://doi.org/10.19173/irrodl.v13i3.1174

[16] R. Ramadhani, U. M. A. M.Rofiqul, A. Abdurrahman, M. SYAZALI. The effect of flippedproblem based learning model integrated with LMSGoogle Classroom for senior high school students. Journal for the Education of Gifted Young Scientists, 7 (2) (2019) 137-158. DOI: https://doi.org/10.17478/ jegys. 548350

[17] C. M. Plump, J. LaRosa. Using Kahoot! in the classroom to create engagement and active learning: A game-based technology solution for eLearning novices. Management Teaching Review, 2 (2) (2017) 151-158. DOI: https://doi.org/10.1177/2379298116689783

[18] R. A. S. Al-Maroof, M. Al-Emran. Students Acceptance of Google Classroom: An Exploratory Study using PLS-SEM Approach. International Journal of Emerging Technologies in Learning, 13 (6) (2018) 99. 